MOLNÁR ANNAMÁRIA

\title{
Vocavere eam preterea multis nominibus: a boccacciói Ops nyomában
}

\begin{abstract}
Ops istennö már az ókori irodalmi hagyományban is - mind névalakjait, mind a hozzá társított funkciókat tekintve - rendkívül komplex istennóként van jelen. A böség, a gazdagság, a termékenység és a Föld istenségeként számos néven emlitik öt (többek között Opis, Rhea, Tellus vagy leginkább Cybelé), és ezzel párhuzamosan különféle szerepeket tulajdonítanak neki, amelyek között egyértelmü distinkció nem születik, sem az antikvitásban, sem a középkorban. Tanulmányomban azt kívánom bemutatni, hogyan értelmezi mindezeket az Opshoz köthetö, antik irodalmi elemeket a középkori hagyomány szüröjén keresztül Boccaccio. Milyen attribútumok és interpretációk jutnak el hozzá, és forrásai alapján hogyan alkotja meg az istennőről szóló leírásait a De mulieribus claris és a Genealogia deorum gentilium soraiban? Milyen ellentmondásokba keveredik a filológus és a narrátor Boccaccio és ezek vajon feloldhatók-e? Ops alakja Boccaccio interpretációjában tehát szemléletes példája lehet annak, milyen kihívásokkal találja magát szemben a filológia hajnalán egy, az elödeitól származó ismeretek feldolgozására törekvő szerző. ${ }^{1}$
\end{abstract}

Kulcsszavak: Ops, Boccaccio, Genealogia deorum gentilium, De mulieribus claris, forrásfeldolgozás

\section{Ops alakja az antik és a középkori irodalmi hagyományban}

Ops alakja egy rendkívül összetett hagyományokkal rendelkező istennőt rejt, akinek talán nem a legismertebb névalakját választotta ki Boccaccio a Genealogia deorum gentilium ${ }^{2}$ és a De mulieribus claris fejezeteinek címadása során. Ahogyan mindkét müben szereplő önálló fejezetei, vala-

\footnotetext{
${ }^{1}$ A publikáció elkészítését az MTA-SZTE Antikvitás és Reneszánsz: Források és Recepció Kutatócsoport (TK2016-126) támogatta.

${ }^{2}$ A mü egyes fejezeteire a továbbiakban, a főszövegben és a lábjegyzetekben egyaránt, a GDG rövidítés utal.
} 
mint más mitológiai alakok leírásaiban való szerepeltetése is bizonyítja, nem csupán a hozzá köthető hagyományok szerteágazóak, hanem az istennő egyes névalakjai is számos kérdést vetnek fel, mindez pedig a görög-római mitológia egyik legrejtélyesebb és számos ellentmondással teli szereplőjévé teszi őt.

Ha a Boccaccio számára is könnyebben hozzáférhetô és érthető latin nyelvü irodalmi hagyományból indulunk ki, láthatjuk, hogy már Varro is felveti annak problémáját, hogy az istennőt számos névvel illették (Ops, Proserpina, Vesta), ám valamennyi elnevezése egyetlen elem, a Föld köré csoportosítható, vagyis Tellus alakjához kapcsolható. ${ }^{3}$ Ezt a gondolatmenetet viszi tovább Varrót idézve Ágoston, ${ }^{4}$ aki úgy érvel, hogy hiába a számos névalak, az mind egy istennőt rejt, ahogyan bárkinek lehet több tulajdonsága és jellemzője egyszerre. A névalakok megsokszorozásáért pedig az antikvitás emberének hibás gondolkodásmódját teszi felelőssé Ágoston, aki nagy valószínűséggel Boccaccio egyik meghatározó forrása volt az istennő alakjának ábrázolása során, nem csupán jellemzőinek összegyüjtése, de alakjának Tellushoz kapcsolása szempontjából is.

A Boccaccio számára mind elsődleges, mind másodlagos forrásból hozzáférhető Ovidius a Fastiban ${ }^{5}$ megörökíti a Megalesia, vagyis Cybelé

\footnotetext{
${ }^{3}$ Varro álláspontjáról és Ops alakjáról, ünnepeiről az ókori Rómában ld. MiANO (2015: 98-127).

${ }^{4}$ Aug. Civ. Dei. 7, 24: Deinde adiungit et dicit, Tellurem matrem et nominibus pluribus et cognominibus quod nominarunt, deos existimatos esse complures. "Tellurem, inquit, putant esse Opem, quod opere fiat melior; Matrem, quod plurima pariat; Magnam, quod cibum pariat; Proserpinam, quod ex ea proserpant fruges; Vestam, quod vestiatur herbis. Sic alias deas, inquit, non absurde ad hanc revocant." Si ergo una dea est, quae quidem consulta veritate nec ipsa est, interim quid itur in multas? Unius sint ista multa numina, non tam deae multae quam nomina. Sed errantium maiorum auctoritas deprimit et eundem Varronem post hanc sententiam trepidare compellit. Adiungit enim et dicit: "Cum quibus opinio maiorum de his deabus, quod plures eas putarunt esse, non pugnat." Quo modo non pugnat, cum valde aliud sit unam deam nomina habere multa, aliud esse deas multas? "Sed potest, inquit, fieri ut eadem res et una sit, et in ea quaedam res sint plures." Concedo in uno homine esse res plures, numquid ideo et homines plures? Sic in una dea esse res plures, numquid ideo et deas plures? Verum sicut volunt, dividant conflent, multiplicent replicent inplicent.

${ }^{5}$ Ov. F. 4, 179-372. Ebben a leírásban is hangsúlyos szerepet töltenek be, valamint az egyik legelső elemként jelennek meg a felsorolásban a zajkeltésre szolgáló, öblös réz-
} 
ünnepének szokásait, amelynek elnevezése a görög Megalé Métér, vagyis Nagy Istenanya elnevezésre vezethető vissza. Ebben a leírásban a Cybelé néven kívül jelzői (Berecyntia tibia) szerepben találkozhatunk a Berecyntia alakkal, amely az ovidiusi szóhasználatban a frígiai kultusz során használt síp származási helyére utal. Ezzel szemben Vergiliusnál sokkal hangsúlyosabban beépül a Berecyntius melléknév az istennő elnevezésbe, ugyanis az Aeneis 6, 784-ben Cybelére a Berecyntia mater elnevezést használja a szerző. Ez a névalak Boccacciónál is szerepel a GDG 3, 2-ben Ops egyik lehetséges elnevezéseként, amelynek forrásaként szerzőnk ugyan Fulgentiust nevezi meg, ám ahogyan azt a későbbiekben látni fogjuk, a névalak lehetséges értelmezései között vissza fog köszönni a vergiliusi gondolatmenet is. Az Ops elnevezés is előfordul a Fastiban, ám csupán egyszer, a 6, 285-ben, ahol Ceres és Iuno anyjaként nevezi meg őt Ovidius.

A középkori szerzők között Rabanus Maurus, akinek De universo (avagy De rerum naturis) c. müvéről szintén feltételezhetjük, hogy Boccaccio forrásaként szolgált az antik világ isteneinek és istennőinek ábrázolásakor, Ceres alakját használja kiindulópontként, amikor Opsról tesz említést. Szerinte ugyanis Ceres egyik elnevezése Ops, de ezen kívül felsorolja a Proserpina, Vesta, Magna Mater és az Alma névalakokat is, amelyeket szintén Ceres lehetséges elnevezéseinek vél. ${ }^{6}$

Amikor pedig az egyes szerzők, köztük Boccaccio is, a Rhea vagy Rheia névalakot említik, akkor az istennő görög elnevezésére utalnak. A

dobok, amelyek az ovidiusi változat szerint arra a mitológiai történetre vezethetők vissza, amikor Rhea el akarta rejteni gyermekét, Iuppitert Saturnus elől, aki félve a jóslattól, miszerint gyermeke fosztja meg őt hatalmától, minden korábbi gyermekét felfalta. A hangszerek pedig azt a célt szolgálták, hogy titokban tartsák a csecsemő Iuppiter sírását. Ovidius megemlíti továbbá az istennő oroszlánok húzta fogatát és tornyos fejdíszét, illetve Attisz történetét is, akinek Sagaris nimfa iránt érzett szerelmi vágya okozta vesztét. A leírás további részében Ovidius Cybelé kultuszának Rómába jutását örökíti meg.

${ }^{6}$ Rab. Maur. De universo 15, 6: Cererem id est terram a creandis frugibus asserunt dictam, appellantes eam nominibus plurimis. Dicunt etiam eam et Opem, quod opere melior fiat terra. Proserpinam quod ex ea proserpiant fruges. Vestam, quod herbis vel variis vestita sit rebus uvel avis vastando. Eandem et tellurem et matrem magnam fingunt turritam cum timpano, et gallo, et strepitu cimbalorum. Matrem vocatam quod plurima pariat. Magnam quod cibum gignat. Almam, quia universa animalia fructibus suis alit. 
görög mitológiában az istennő alakja szintén szorosan összekapcsolódik a teremtéssel, hiszen a mítoszok tanúsága szerint tőle és testvérétől, egyben férjétől, Kronosztól származik az olümposzi istenek első nemzedéke. A Földdel való szoros kapcsolata, amely később a római hagyományban Tellusszal való azonosságát feltételezi, anyja Gaia, a Földanya révén alakulhatott ki. A görög mitológiai hagyomány említést tesz még arról, hogyan falta fel Kronosz a Rheától született gyermekeit, akik egy jóslat szerint uralma végét jelentették, míg végül Zeusz születésekor felesége cselhez nem folyamodott és a gyermek helyett egy követ adott át Kronosznak. Az újszülött Zeuszt pedig Kréta szigetére menekítette és sírását a koribantok rézből készült hangszerekkel keltett zajjal nyomták el.7 Mindebből azonban csak a koribantokat említő rész olvasható az istennőről szóló fejezetben, a többi elemről Ops egyik önálló leírásában sem tesz említést Boccaccio. Ennek több lehetséges magyarázatát feltételezhetjük. Ha a Kronosz névből kiindulva keressük a választ a kérdésre, nem zárható ki, hogy a görög névalak már önmagában elegendő okot szolgáltatott a történet mellőzésére Ops leírásában. Kronosz neve ugyanis csak a Genealogia egyetlen fejezetében, a második Venus leírásában $(G D G 3,23)$ szerepel, ott is csupán egy Fulgentius alapján megfogalmazott érv alátámasztására, amelynek elengedhetetlen részét képezi a megállapítás, hogy Saturnus görög nevének, a Kronosznak jelentése 'idő'. Vagyis Boccaccio, amikor lehetősége volt, latin nyelvű munkáról lévén szó, a Genealogiában igyekezett a görög nevek helyett a latinokat használni, így Kronosz esetében is, ami ebben az esetben látszólag egyet jelentett egy róla szóló történet mellőzésével. Ugyanakkor Boccaccio nyilvánvalóan tudatában volt a két név mögött rejlő isten azonosságának, így a mú egy későbbi részébe, Saturnus fejezetébe $(G D G 8,1)$ beépítette Ops cselét. Ennek tudatában pedig akár szándékosan is mellőzhette és későbbre halaszthatta a történtek megörökítését, mindennek ellenére mégis különös, hogy nem az adott tett megvalósítójánál említi azt részletesebben, bár ennek hátterében akár az is állhat, hogy Saturnus sokkal ismertebb alakja a mitológiának.

A fent említett irodalmi források információgazdagsága és ellentmondásai egyaránt hüen szemléltetik azt a kezdettől fogva létező, vagy-

${ }^{7}$ Rhea történetét ld. KERÉNYI (1977: 65-66). 
is magától a forrástól kiinduló nehézséget, hogy Ops számos névvel, tulajdonsággal és tettel felruházott istennőként állt már az ókori olvasó előtt is, így lényegében egy eleve kaotikusnak mondható hagyományt igyekeztek rendszerezni a későbbi források is. Így Boccaccio már egy kétszeresen is tisztázni próbált, ám annál ellentmondásosabbá tett hagyománnyal találta magát szemben, amikor Ops alakjának feldolgozására vállalkozott.

Mindaz, amit Boccaccio a forrásai révén szintetizálni tudott az istennőről, azt eredményezte, hogy Ops a Genealogiában az eunuchok által szolgált, oroszlánfogatos Cybelé alakjában rajzolódik ki előttünk, az alábbiakban részletesen ismertetett számos egyéb lehetséges, ám annál homályosabb eredetü névvel illetve (köztük például Terra, Ceres vagy éppen Magna Mater néven), míg a De mulieribusban egyszerü halandóként, akit a mü harmadik fejezete szerint Ops vagy Rhea néven őrzött meg istenségként a köztudat. Mindezek alapján jelen tanulmány tehát az alábbi kérdésekre fókuszál: miért tartotta említésre méltónak Boccaccio mindkét müvében az istennőt? Tudatos szerzői döntés vagy épp a véletlen emelte a De mulieribus hat istennője közé Opsot? Továbbá fontos azt is elemzés tárgyává tennünk, milyen kapcsolat fedezhető fel az őt középpontba állító két boccacciói jellemzés között. Történik-e változás az istennőről alkotott képben, és ha igen, az vajon az alakját érintő kérdések rendszerezését vagy inkább teljesen új nézőpontok bevezetését hozza magával? Mennyire erős a két mü között fennálló kapcsolat, és hogyan épülnek egymásra, vagy éppen mondanak ellent a korábbiaknak a jellemzések egyes elemei?

\section{Opshoz köthető névalakok a Genealogiában}

Mielőtt a Genealogiában és a De mulieribusban az Opsot tárgyaló önálló fejezetek részletes ismertetésére és összehasonlítására kerülne sor, érdemes összefoglalni, hogyan használja fel Boccaccio Terra-fejezetéből $(G D G 1,8)$ kiindulva az istennő különféle névalakjait érintő hagyományt és mennyire következetesen építi be értesüléseit az egyes leírásokba. Ugyanis nem kizárólag a fent említett irodalmi források, hanem már maguknak a névalakoknak az áttekintése is rávilágíthat arra, milyen nehézségekkel kellett szembenéznie Boccacciónak Ops történeteinek szintetizálása során. 
A kérdés már igen hamar, az első könyv nyolcadik fejezetében (De Terra ex filiis Demogorgonis VIII ${ }^{a}$, que ex incognitis parentibus $V$ genuit filios; quorum primus Nox, secundus Tartarus, III ${ }^{u s}$ Fama, IV ${ }^{u s}$ Taigetes $V^{u s}$ Antheus), Terra kapcsán megjelenik. A Terrának szentelt fejezetben ugyanis Boccaccio megemlíti azt a számos névalakot, amelyen az istennőt nevezték. A felsorolásban az alábbi nevek kapnak helyet: Terra, Tellus, Tellumon, Humus, Arida, Bona Dea, Magna Mater, Fauna, Fatua. Ezt követően arra hívja fel a figyelmet a leírás, hogy több olyan néven is említik őt, amely más istennőkével közös. Ekkor jelenik meg az Ops névalak is, a Cybelé, a Berecyntia, a Rhea, a Iuno, a Ceres, a Proserpina, a Vesta, az Isis, a Maia és a Medea elnevezésekkel együtt. ${ }^{8}$ Ezek közül több, ahogyan azt a későbbiekben látni fogjuk, valóban visszaköszön Ops önálló leírásában, ezzel is alátámasztva a névazonosságot és a Terra alakjával való azonosítást feltételező hagyomány követését. Boccaccio ugyanakkor már itt arra figyelmeztet, hogy ez utóbbi névalakokat mindig az adott istennőről szóló részben elemzi és értelmezi. Terra fejezetében tehát csak az első csoportban felsorolt névalakok lehetséges eredetét foglalja össze. Ezek közül a Bona Dea és a Magna Mater alakokat érdemes kiemelnünk, ugyanis azáltal, hogy Boccaccio a későbbiekben Cybeléhez is kapcsolja Opsot, akinek lehetséges elnevezései között a fenti kettő is szerepel, említésük nem mellőzhető.

A Bona Dea név magyarázatért Macrobius Saturnaliájához fordul Boccaccio. Eszerint az elnevezés hátterében a javak állnak, az istennő látja el ugyanis az embereket minden földi jóval, táplálja a rügyeket és a gyümölcsöket, élteti a madarakat és azokat az állatokat, amelyekkel mi emberek is táplálkozunk. A Magna Mater név értelmezése során pedig Boccaccio felülírja forrása értelmezését, miszerint az istenség minden dolgok teremtője, és inkább azt a jóval különösebb lehetőséget valószínűsíti, saját meggyőződésként feltüntetve, hogy az istennő termékeny-

\footnotetext{
${ }^{8}$ Vö. GDG 1, 8, 3: Vocavere eam preterea multis nominibus, ut puta Terram, Tellurem, Tellumonem, Humum, Aridam, Bonam deam, Matrem magnam, Faunam et Fatuam. Habet et preter hec cum quibusdam deabus communia nomina. Dicitur enim Cybeles, Berecinthia, Rhea, Opis, Iuno, Ceres, Proserpina, Vesta, Ysis, Maia et Medea. A müből származó valamennyi idézet forrása az alábbi kritikai kiadás: ZACCARIA (1998).
} 
ségének köszönhetően minden halandót táplál és ölébe fogadja azokat, akikre halál vár. Ezeket az interpretációkat később már valóban nem olvashatjuk Ops fejezetében, a nevek még csak említés szintjén sem kapnak helyet ott, így ezen a ponton Boccaccio hü marad állításához és valóban nem említ egyszer már kifejtett értelmezést.

A többi, Ops szempontjából is releváns névalak esetében hangsúlyoznunk kell, hogy értelmezéseik részben nem önálló fejezetben kapnak helyet a Genealogiában, hiszen számos esetben maguk az istennők nem címadói egyetlen fejezetnek sem. Így Berecyntia, Rhea vagy Cybelé éppen Ops fejezetében $(G D G 3,2)$ szerepelnek a legnagyobb részletességgel, ahol sor kerül a Boccaccio által az első könyvben előrevetített névalakértelmezésre.

Arra azonban találunk példát, hogy a mü más részeiben további ismereteket közöl velük kapcsolatban Boccaccio. Így tesz például Cybelé esetében is, akinek oroszlánfogata és annak többféle lehetséges értelmezése ugyan szerepel a GDG 3, 2-ben, ám arról, hogy kik is ezek az oroszlánok, már a GDG 10,57-ben, Hippomenész és Atalanté történetében olvashatunk. Boccaccio ebben a fejezetben meséli el, hogyan győzte le Hippomenész, Venus közbenjárásával, a versenyfutásban kivételes gyorsaságú Atalantét: a szerelem istennője a Heszperidák kertjéből származó három aranyalmát ajándékozott neki, hogy azokat eldobva terelje el futás közben a lány figyelmét. Miután Hippomenész ily módon elnyerte Atalanté kezét, türelmetlenségében megfeledkezett Venus ajándékáról, és Cybelé ligetében teljesítette be szerelmi vágyát. Az átélt gyönyörök miatti gőgjüket megbosszulni akaró Cybelé vagy a segítsége után méltatlanul mellőzött Venus, ebben nem foglal egyértelmüen állást Boccaccio, ezt követően haragjában oroszlánokká változtatta és Cybelé fogathajtóivá tette a fiatalokat. ${ }^{9}$

Ceres és Iuno önálló fejezeteiben Ops a két istennő anyjaként szerepel, így az ő esetükben azt feltételezhetjük, hogy Terra névalakjainak felsorolásakor a mitológiai hagyományban eleve meglévő diszkrepanci-

${ }_{9}$ GDG 10, 57, 3: Cum qua dum letus in patriam abiret Yppomenes, fervoris impatiens et suscepti a Venere muneris immemor, in lucum Cybeles illam deduxit, et ibi cum ea concubuit. Ex quo seu Veneris, seu matris deum indignatione, factum sit, amantes in leones versi sunt, et currui Cybeles additi. 
ákat Boccaccio egyszerúen átemelte, akkurátus filológusként dokumentálta. Ugyanis, ha elfogadjuk a GDG 1, 8-ban leírtakat, miszerint Terra bizonyos hagyományok szerint azonos Opsszal, Ceressel, Proserpinával vagy akár Iunóval, azáltal az anyát azonosnak vesszük a lányával. Ennek az ellentmondásnak a feloldására Boccaccio nem vállalkozik, egyik istennő esetében sem említi ugyanis újra, hogy Ceres, Iuno és Ops egyazon istennő, Terra elnevezései lennének.

Maiát ugyanakkor Terrához köthetően négyszer említi a Genealogiában $(4,35 ; 9,1,1 ; 12,62$, 1 és 12, 70, 2) Boccaccio. Nem egy fejezet fószereplőjeként háromszor szerepel, köztük Vulcanus leírásában, ahol csupán annyit tudunk meg róla, hogy az antik mítoszok számos Vulcanusa közül az egyiknek volt a felesége, és lehetséges, hogy nem is Maiának, hanem Maiestasnak hívták. Az őt középpontba állító önálló fejezet, a GDG 4, 35 azonban sokkal részletesebb ismeretanyaggal szolgál Maia alakját illetően. Azontúl, hogy visszatér a dilemma, vajon Vulcanus felesége, vagy Iuppiter szeretője volt-e, valamint, hogy Maia vagy Maiestas volt-e a neve, kultuszára és a hozzá társított hiedelmekre is kitér a leírás. Miután Boccaccio megemlíti azt az elképzelést, amely szerint Maia hozza el a nyarat, ennek hátterében azt sejti, hogy az istennőt a Földdel azonosították. Ezt követően Maia nevének többféle alakját (Ops, Bona Dea, Fauna, Terra, Fatua, vagyis mind olyan elnevezések, amelyeket korábban a GDG 1, 8-ban is összekapcsolt) és azok lehetséges magyarázatát adja, amelyek között szerepel a május hónap elnevezése, vagy éppen a nevében rejlő nagyság elnevezés is. E részletekbe menő értelmezéssel ellentétes hozzáállásra is találunk példát Boccaccio részéről. Említsük meg Medea példáját, akinek ugyan önálló fejezetet szentel Boccaccio, abban mégsem tér ki nevének etimológiájára, olyannyira, hogy még Terrával való azonosságának lehetőségét sem említi meg a későbbi fejezetekben.

A különféle névalakok összevetésének lezárásaként érdemes még kitérni Fauna alakjára, akinek önálló fejezete a GDG 8, 12-ben szemléletes összefoglalását adja mindannak, amit Boccaccio Terráról (ezáltal pedig Opsról és valamennyi elnevezéséről) leírt. Ugyanakkor rávilágít arra, hogy szerzőnk a lehetetlen rendszerezésére vállalkozott, így ő maga is jobbnak látta, ha röviden is, de a fejezetet lezáró sorokban a következő 
szavakkal ismeri be vállalkozása kudarcát: "Quas quidem ego ambages et circumitiones detestor et omitto libens." (GDG 8, 12, 4). Ebben a Faunát tárgyaló fejezetben ugyanis, nevének lehetséges értelmezésein túl, szintén valamennyi, Terrához köthető névalakot felsorol. Bona Deával, Opsszal, Fatuával, de még Proserpinával is azonosítja őt, ugyanakkor Maiának és a Föld istennőjének is nevezi, tehát újra egybeolvaszt mindent, amit más fejezetekben szétválasztott.

Ahogyan a fenti áttekintés alapján is megállapítható, már az egyes névalakok megkülönböztetése sem történik meg egyértelmüen a Genealogiában, vagy éppen használatuk következetlenségeket mutat. Mindezek alapján azt feltételezhetjük, hogy Boccaccio számos esetben csupán szöveghűen követi forrásainak tartalmát. Amikor érvelése alátámasztása vagy a narratíva úgy kívánja, szó szerint átveszi azok értesüléseit anélkül, hogy figyelmet fordítana a bennük szereplő névalakok egységesítésére vagy az egyes istennőkhöz társított cselekedetek elkülönítésére. Ugyanakkor számos esetben talán éppen magukkal a forrásokkal magyarázható egyes névalakok megjelenése az Opsszal összefüggésbe hozható fejezetekben. Amint relevanciáját veszti egy-egy érv, eltünik az adott névalak és vele együtt az azt megemlítő forrás is. Ezzel együtt pedig megszünik az az igény is Boccaccióban, hogy a források szintetizálása révén mindent egységbe rendezzen. Ez a hozzáállás, bár nem igazolható minden kétséget kizáróan, mégis bizonyítható például akkor, amikor Terra, majd belőle kiindulva Ops névalakjait veszi sorra. Nem zárható ki az sem, hogy a többi fejezet információi (Ops esetében főként a GDG 1,8) alapján az egyes elnevezések közötti kapcsolatot Boccaccio evidensnek vette, bár ez az Ops alakját övező ellentmondások miatt nem tünik valószínünek.

Nem minden esetben ügyel arra sem Boccaccio, hogy a korábbi fejezetekben előrevetített információkat később megossza olvasóival, ahogyan azt az elmaradt névértelmezés, vagy az egyszer már elkülönített ismeretek újbóli egybeolvasztása is alátámasztja. A fentiek alapján kirajzolódnak Boccaccio filológusként alkalmazott alapvető munkamódszerei, amelyek révén igyekszik a legtöbb antik és középkori irodalmi forrást felkutatni és a bennük található ismereteket olvasóival megosztani, azokat több szinten értelmezni, szükség esetén magyarázni. Ám aho- 
gyan Ops tettei és számos istennőhöz kapcsolható névalakjai is bizonyítják, a boccacciói munkamódszerek helyenként forráshasználati pontatlanságokról és az azok értelmezése körüli tanácstalanságról tesznek tanúbizonyságot, ezzel is alátámasztva egy születőben lévő tudomány müvelésének nehézségeit.

\section{Ops alakja és kultusza a Genealogiában}

Ezen előzmények ismeretében talán teljesebb képet kaphatunk arról, hogyan és miért éppen abból a nézőpontból látta és láttatta Boccaccio Opsot a Genealogiában, ugyanakkor egyre hangsúlyosabban vetődik fel a kérdés, miért tartotta szükségesnek alakjának beillesztését a De mulieribusba. Mind a müvek feltételezett kronológiája, ${ }^{10}$ mind az ismeretek gazdagsága azt indokolja, hogy a vizsgálatot a Genealogia soraiban szükséges kezdeni.

Ops vagy Opis, Saturnus felesége, Boccacciónál önálló fejezetben kizárólag egyszer, a GDG 3, 2-ben (De Opi prima Celi filia et Saturni coniuge) szerepel. ${ }^{11}$ Ebben a Genealogiára jellemző módon felépített leírásban, amely a források alapján feltárható jellemzők bemutatásától azok többszintű elemzéséig terjed, Boccaccio először ismerteti az istennő származását és a hozzá köthető kultuszokat, hagyományokat. A leírás az istennő családfáját Lactantiusra hivatkozva rekonstruálja. Ebből megtudhatjuk, hogy Ops Caelum és Vesta gyermeke, illetve Saturnus felesége volt, továbbá anyja Iuppiternek és még számos istennek. ${ }^{12}$ A leírás érdekessége, hogy a Boccaccio által felsorolt további információk ezt követően kizárólag Ops kultuszára vonatkoznak, annak elemeit sorolják fel, illet-

\footnotetext{
10 A boccacciói művek feltételezett kronológiája szerint a két latin prózai mű közül a Genealogia íródott korábban, ugyanakkor nem zárhatjuk ki, hogy Boccaccio valamennyi nagy, latin nyelven írt müvén párhuzamosan dolgozott. Erről ld. KIRKHAM (2013: xiiixix).

${ }^{11}$ Ops neve említés szintjén, illetve a jelen fejezetben foglaltakra visszautalva az alábbi helyeken szerepel a Genealogiában: $1,8,3 ; 3,1,1 ; 3,4,2 ; 4,1,3$ és 5-6; 4, 35, 6; 8, 1, 1. 6-7. 12-13. 30-31; 8, 3, 1; 8, 4, 1 valamint $8 ; 8,5,1 ; 8,6,1$ továbbá $6 ; 8,8,1 ; 8,12,2 ; 9,1,1.5$. $22 ; 10,1,1 ; 11,1,1$. Ezeken az előfordulásokon kívül egy téves boccacciói forrásértelmezés szerint Vulcanust, Nylus fiát emlegették Ops néven az egyiptomiak.

${ }^{12}$ Lactant. Div. inst. 1, 11: Iupiter, [...] qui ex Saturno et Ope natus est. Enniusra hivatkozva az 1, 14-ben ez olvasható: Exin Saturnus uxorem duxit Opem.
} 
ve megkísérelnek magyarázatot adni létrejöttének körülményeire, az istennő konkrét tetteinek említése azonban elmarad. Még egy olyan híres mitológiai történetet sem tart említésre méltónak itt Boccaccio, mint azt, hogyan mentette meg Ops a gyermekeit attól, hogy apjuk, Saturnus, hatalma elvesztésétől való félelmében felfalja őket. Az epizód azonban a GDG 4, 1-ben és 8, 1-ben részletesen kifejtésre kerül.

Mielőtt magára a kultusz ismertetésére kerülne a sor, Boccaccio a De mulieribusban szereplő valamennyi istennő esetében nyomatékosan hangsúlyozott, azonban a Genealogiában is jelenlévő euhémerizmussal különféle lehetőségeit tárja fel annak, miért válhatott Opsból istennő. Eszerint mindennek hátterében emberi vakság áll. Az antik világ teológusai $^{13}$ azért, hogy tulajdon hibáikat leplezzék, vagy elrejtsék a köznép elől az igazságot, vagy csupán azért, hogy hízelegjenek a hatalmas királynak, Iuppiternek, figyelmen kívül hagyták a történelmet és olyan csodálatos mesékkel ruházták fel Opsot, amelyek istennővé tették őt.

A róla fennmaradt történetek ugyanis az istenek anyjának tartották őt, attribútumaiként oroszlánok által hajtott fogatot, egy tornyos fejdíszt és jogart tulajdonítottak neki, továbbá egy ágakból és növényekből készült ruhát. Kíséretéhez pedig gallusoknak nevezett ${ }^{14}$ eunuchok tartoztak, akik doboltak és rézből készült hangszerekkel keltettek zajt. Az Ops kultuszához tartozó információkat azzal zárja, hogy az istennőt üres székekkel vették körbe és fegyveres koribantok ${ }^{15}$ őrizték. Mindezekből megállapítható, hogy Ops alakját sokkal inkább a Cybeléként ismert is-

\footnotetext{
${ }^{13}$ Nem feltétlenül a vallási értelemben vett teológusokra utal itt Boccaccio, a szóhasználatot értelmezhetjük a költőkre történő utalásként is, ahogyan arra Boccaccio a Dante élete huszonkettedik fejezetében (A költészet védelme) is utal: „higgyenek akkor Aristotelesnek [...] ő is megerősíti azt a tételt, hogy a költők voltak az első hitbölcselők".

${ }^{14}$ Cybelé eunuch papjainak római elnevezése. Az első gallusok azután érkeztek Rómába, hogy a szenátus hivatalossá tette az istennő kultuszát, ugyanis a római polgároknak tilos volt kasztrálni magukat (ez alól kivételt jelentett Claudius császár kora).

${ }^{15}$ Cybelé papjainak Frígiában használatos neve, akik az istennőt kísérve lendületes, olykor orgiasztikus táncot jártak, amely közben néha még meg is sebesítették magukat. Származásukról többféle, egymásnak ellentmondó történet létezik. Többek között Kronosz, vagy Héliosz és Athéné, valamint Zeusz és Thália gyermekeiként tartják őket számon.
} 
tennőhöz kapcsolja az eddigi leírás, ismertetőjegyei és kultuszának elemei ugyanis mind ezt erősítik.

Rómába behozott, idegen eredetű kultuszról lévén szó, feltételezhetjük, hogy a boccacciói források is szükszavúan írtak magáról az istennőről, és sokkal inkább kultuszának gyakorlására helyezték a hangsúlyt, illetve igyekeztek valamiféle magyarázatot találni annak szokatlan kellékeire és elemeire. Ez magyarázhatja, hogy egyetlen konkrét tettet sem tudott hozzá társítani Boccaccio, így a kultusz rövid bemutatása után azonnal az egyes elemek értelmezésére tér rá, azokat azonban igyekszik minél többféle szempont és értelmezési lehetőség szerint bemutatni. Elsőként azt igyekszik feltárni, hogyan is lehetséges, hogy Opsot az istenek anyjaként tartják számon. Erre egy szűkszavú, euhémerisztikus magyarázatot ad Boccaccio, amely szerint azok az emberek is közönséges földi halandók voltak, akik társaikat istenekké tették, ebből következően Opsra is egyszerü asszonyként kell tekintenünk. Ugyanilyen, az istennőt a földi élethez kapcsoló magyarázatot ad Boccaccio a tornyos fejdíszre, a ruhára és a jogarra is. Szerinte ugyanis Ops maga a Föld, amelyet városok és várak ékesítenek, ruhája pedig a Földet díszítő erdők és gyümölcsösök, illetve az azt benépesítő különféle fajok szimbóluma. Jogara pedig nem más, mint a királyságok és birodalmak gazdagságának és hatalmának szimbóluma.

Oroszlánfogata is a korábban felépített értelmezést hivatott erősíteni. Míg a fogat meglétét egyértelmüen az évszakok körforgásaként értelmezi Boccaccio, addig az oroszlánok jelenlétére többféle lehetséges magyarázatot ad. Az egyik szerint, amelyben Boccaccio Solinusra hivatkozik, ${ }^{16}$ a földmüvesek és az oroszlánok között von párhuzamot és a gondos előrelátás szükségességére hívja fel a figyelmet. Ahogyan az

\footnotetext{
${ }^{16}$ Boccaccio Mirabiliumként említi Solinus müvét, amelynek címe valójában Collectanea rerum memorabilium. Solinus sokszor felhasznált szerző Boccacciónál, műve a MAZZA (1966: 43) által készített leltárjegyzék szerint a Parva libraria gyüjteményének részét képezte. Érdemes továbbá kiemelni, hogy ugyan Boccaccio itt Solinusra mint forrásra hivatkozik és ZACCARIA (1998: 1632, 13. jz) az információ helyeként a Solin. 2, 27, 20-at jelöli meg, a vonatkozó szöveghelyen a boccacciói értesülésnek nyoma sincs: Saepti a venantibus obtutu terram contuentur, quo minus conspectis venabulis terreantur. Numquam limo vident minimeque se volunt aspici. Cantus gallinaceorum et rotarum timent strepitus, sed ignes magis.
} 
oroszlánok farkukkal eltüntetik lábnyomaikat, hogy a vadászok ne találjanak rájuk, ${ }^{17}$ úgy fedik be az elvetett magot a földmüvesek, hogy a madarak ne tegyenek kárt a vetésben. A második értelmezés az oroszlán erejére helyezi a hangsúlyt. A földmüvesnek ugyanis mindenki másnál erősebbnek kell lennie, ahogyan az oroszlán csontjai is erősebbek a többi állatéinál. Az utolsó interpretáció szerint pedig, ahogyan az oroszlán az állatok királya, úgy utalnak a fogatot húzó állatok a földi uralkodókra.

Szintén számos értelmezési lehetőséget vetnek fel az Opsot körülvevő üres székek, ám közös bennük, hogy Boccaccio továbbra is a földi élet és világrend alapján igyekszik ezeket racionalizálni. Az üres székek elsőként a járványok és a háborúk miatt kiürült házak és városok szimbólumai, majd a világ lakatlan területeinek jelképeivé válnak. Boccaccio szerint azonban megtestesíthetik azt is, hogy a Föld mindig készen áll olyan új emberek fogadására, akik még csak ezután születnek meg. Az utolsó értelmezési lehetőség ezúttal is a hatalomhoz kapcsolható, akárcsak az oroszlánok húzta fogat esetében. Ennek értelmében az uralkodók figyelme soha nem lankadhat, mindig ébernek kell lenniük, hiszen mindig akadnak új, megoldandó kihívások.

A kultuszában közreműködő papok szerepének értelmezése során a koribantok egy meglehetősen rövid és általános magyarázatot kapnak, amely kizárólag a fegyverükre korlátozódik. Eszerint a hazáért harcolni kell és a megmenekülés reményében fegyvert kell fogni. Ezzel bármilyen fegyveres alakulatot jellemezni lehetne, így nem tartozik a legjobban sikerült interpretációk közé, ám Boccaccio minden bizonnyal nem talált túl sok forrást ennek értelmezésére vonatkozóan, így végül Rabanus Maurust vette alapul, akinél más szavakkal ugyan, de lényegét tekintve ugyanez az értelmezés szerepel. ${ }^{18}$

\footnotetext{
17 A boccacciói említés hátterében az állhat, hogy az oroszlánoknak ezt a szokását a Physiologus óta valamennyi középkori bestiárium és enciklopédia említi, tehát Boccacciónál ez az elem egyfajta toposként kerülhetett elő. Talán ezért is tévedett forrása megnevezésekor, aki akár lehetett Isidorus (Etym. 12, 2, 5: cauda sua cooperiunt vestigia sua, ne eos venator inveniat) vagy Rabanus Maurus (De universo 8,1), akinél szó szerint a már idézett megfogalmazás szerepel. Az oroszlánnak tulajdonított szokásokról és azok értelmezéséről ld. VíGH (2019: 243-249).

18 Rab. Maur. De universo 15, 6: Coribantes eius ministri cum strictis gladiis esse finguntur, ut significetur omnis pro terra sua debere pugnare.
} 
Sokkal részletesebb, ezen felül új elemet is hozó rész a gallusokat magyarázó. Ez ugyanis behozza Attisz alakját, megerősítve és hangsúlyossá téve ezáltal az Opsot Cybeléként számontartó hagyományt. Boccaccio, miután röviden összefoglalja az Ops által szeretőjével rajtakapott és féltékenységből kiherélt Attisz történetét, leírja, hogy a kultusz papjait egyfajta iróniaként nevezték el gallusoknak. Ezt követően Macrobius Saturnaliájára ${ }^{19}$ hivatkozva olvashatjuk, hogy Attisz nem más, mint a Nap, aki minden évben élettel tölti be a Földet. Attisz kiherélését pedig kitalációnak tartja és a Nap erejének gyengülésével hozza összefüggésbe, ami ősszel és télen mintha terméketlen lenne, és semmi új létrehozásában nem működne közre. Porfiriosz elmélete szerint, amely szintén helyet kap a fejezetben, Attisz nem más, mint egy virág. Boccaccio a Porfiriosztól származó elméletet Ágoston alapján mutatja be. Eszerint Attisz, aki bizonyos értelmezések szerint a tavasz jelképe, azért vesztette el férfiasságát, mert a virág is lehullik, mielőtt megjelennének a gyümölcsök. A virággal pedig nem magát Attiszt, hanem a férfiasságát kell azonosítanunk, amelynek lehullását nem gyümölcs, hanem meddőség követte. ${ }^{20}$

Mielőtt az istennő különféle névalakjainak felsorolására és azok lehetséges etimológiájának bemutatására térne át, Boccaccio röviden értelmezi a papok által használt hangszereket is. A dobok mellett, amelyek szerinte a Föld két félgömbjét jelképezik, helyet kap az ércből készült hangszerek értelmezése is. Utóbbiak a vasból készült mezőgazdasági eszközök feltalálása és felhasználása előtti időszak jelképeiként je-

\footnotetext{
${ }^{19}$ Macrob. Sat. 1, 21: Solem vero sub nomine Attinis ornant fistula et virga.

${ }^{20}$ Aug. Civ. Dei. 7, 25: Et Attis ille non est conmemoratus nec eius ab isto interpretatio requisita est, in cuius dilectionis memoriam Gallus absciditur. Sed docti Graeci atque sapientes nequaquam rationem tam sanctam praeclaramque tacuerunt. Propter vernalem quippe faciem terrae, quae ceteris est temporibus pulchrior, Porphyrius, philosophus nobilis, Attin flores significare perhibuit, et ideo abscisum, quia flos decidit ante fructum. Non ergo ipsum hominem vel quasi hominem, qui est vocatus Attis, sed virilia eius flori comparaverunt. Ipsa quippe illo vivente deciderunt; immo vero non deciderunt neque decerpta, sed plane discerpta sunt; nec illo flore amisso quisquam postea fructus, sed potius sterilitas consecuta est. Quid ergo ipse reliquus, et quidquid remansit absciso? quid eo significari dicitur? qua refertur? quae interpretatio inde profertur? An haec frustra moliendo nihilque inveniendo persuadent illud potius esse credendum, quod de homine castrato fama iactavit litterisque mandatum est? Merito hinc aversatus est Varro noster, neque hoc dicere voluit; non enim hominem doctissimum latuit.
} 
lennek meg. A kultusz során használt jellegzetes ütőhangszerrel kapcsolatos információkat Boccaccio valószínűleg Ágostontól veszi át, aki pedig Varróra hivatkozva fogalmazza meg álláspontját. ${ }^{21}$ Ugyanakkor a Föld alakja és a hangszer közötti párhuzamot Boccaccio megtalálhatta Rabanus Maurusnál is. ${ }^{22}$

$\mathrm{Az}$ istennőnek szentelt fejezet utolsó részében találkozhatunk először Ops különféle névalakjaival, ám azok között, Boccaccio állítása szerint, jelen fejezetben nem szerepelnek olyanok, amelyek más istennőkkel közösek, illetve olyanok sem, amelyek a Földről (Terra) szóló fejezetben ${ }^{23}$ már említésre kerültek. Az Opson kívül az alábbi névalakokat emeli ki és értelmezi forrásokkal alátámasztva a leírás: Berecyntia, Rhea, Cybele, Alma és Pales. Utóbbi kettő jellegzetessége a többi névalakhoz képest, hogy azokat Boccaccio nem említette a Terráról szóló fejezetben.

Az Ops alakot Rabanus Maurusra hivatkozva ${ }^{24}$ értelmezi úgy, hogy mivel termést és gyümölcsöket hoz, jobbá teszi a Földet. ${ }^{25}$ Berecyntia néven Fulgentius tesz róla említést, ${ }^{26}$ ennek jelentése „a hegyek királynője", amely elnevezés azt hivatott kifejezni, hogy ő az istenek királynője. A nevet tovább elemzi és értelmezi Boccaccio, miszerint a hegyek az istenek, az istenek pedig a magasabb rangú emberek, ám azt tartja a leginkább lehetséges megoldásnak, hogy a nőt egy hegyről vagy Frígia vá-

${ }^{21}$ Aug. Civ. Dei. 7, 24: Eandem, inquit, dicunt Matrem Magnam; quod tympanum habeat, significari esse orbem terrae [...] Cymbalorum sonitus ferramentorum iactandorum ac manuum et eius rei crepitum in colendo agro qui fit significant; ideo aere, quod eam antiqui colebant aere, antequam ferrum esset inuentum. A Cybelének tulajdonított jellegzetes ütőhangszerről részletesen ld. MOLINA (2014: 51-69).

${ }_{22}$ Rab. Maur. De universo 15, 6: quod timpanum habet, significare volunt orbem terrae...

${ }^{23} \mathrm{Vö.} \mathrm{8.} \mathrm{lábjegyzet.}$

${ }^{24}$ Rab. Maur. De universo 15, 6. Rabanus Maurus ugyanakkor a Ceres névalakot tekinti kiindulópontnak, akiről megállapítja, hogy számos névvel illetik, köztük az Ops alakkal is: Dicunt etiam eam et Opem, quod opere melior fiat terra.

${ }^{25}$ A GDG 8, 1, 30-31-ben is szerepel Ops nevének értelmezése, amelyben szintén összekapcsolja az istennőt a Földdel és kitér kultuszának arra az elemére is, amelyben ülve tesznek fogadalmat és megérintik a földet, hogy így is jelezzék, az embereknek a Földanyát kell keresniük. Huic dee sedentes vota concipiunt, terramque de industria tangunt, demonstrantes ipsam matrem terram esse mortalibus appetendam.

${ }^{26}$ Fulg. Myth. 3, 5. Fabula Berecintie et Attis c. fejezetben: Berecintiam dici voluerunt quasi montium dominam; ideo matrem deorum... 
rosáról nevezték el, ${ }^{27}$ ahol istennőként tisztelték. Míg a Rheát egyértelmüen az Ops névalak fordításaként magyarázza, addig a Cybelé alakra ismét többféle elképzelést ismertet. Akad olyan szerző, aki szerint a kultuszban először résztvevőról kapta a nevét, ${ }^{28}$ mások szerint arról a városról, ahol megtalálták a képmását, de forrásai azt is felvetik, hogy a cibel szóról, amely a kultusz közben végzett fejmozgatásra utal. Az Alma névalakot az alo igére vezetik vissza Boccaccio meg nem nevezett forrásai, vagyis a táplálásra, amivel a Földet gazdagítja. A Pales elnevezést pedig a pásztorok használják rá, hiszen ő látja el a nyájakat legelővel.

Azáltal, hogy a különféle névalakokat Boccaccio a fejezet lezárásaként említi, azt a benyomást keltheti, hogy kevésbé tartotta jelentősnek vagy megvalósíthatónak a kérdés tisztázását. Ugyan a nevek magyarázata és értelmezése a Genealogia sajátosságaiból adódóan indokolttá tette, hogy ez a rész mindenképpen a fejezet második felébe kerüljön, mégis az egyes elnevezések interpretációja sokkal inkább felsorolásszerü, a rendszerezés igénye nélkül. Boccaccio előszeretettel használt - főként középkori - irodalmi forrásaira (Fulgentius, Rabanus Maurus) alapozza gondolatmenetét, az ezekben foglaltakat azonban nem kérdőjelezi meg, sokkal inkább azok megemlítését tartja szem előtt.

\section{Ops a De mulieribusban}

$\mathrm{Az}$ istennő alakja teljesen más hangsúlyokkal, egy lényegesen rövidebb és a Genealogiához ugyan kötődő, ám hozzá képest számos információval szegényebb leírásban kap helyet a De mulieribus 3-ban, a De Opi Saturni coniuge c. fejezetben. A két önálló leírás közötti hasonlóságot az euhémeroszi világkép nyomatékosítja ugyan, ám a De mulieribusban sokkal nagyobb hangsúlyt kap az antik hitvilág megkérdőjelezése és Ops isteni mivoltának cáfolata. A Genealogiában meglévő, az isteni mivoltot kiemelő elképzelések a De mulieribusból teljesen eltünnek és részben új álláspontok veszik át a helyüket. Boccaccio állítása szerint Ops semmiféle jelentős tettet nem hajtott végre, így nem is maradt volna meg

\footnotetext{
${ }^{27}$ Verg. Aen. 6, 784-787: qualis Berecyntia mater / invehitur curru Phrygias turrita per urbes / laeta deum partu, centum complexa nepotes, / omnis caelicolas, omnis supera alta tenentis.

${ }^{28}$ Serv. Aen. 3, 111: alii dicunt Cybelum sacerdotem eius primum fuisse in Phrygia, et ab eo Cybelen dictam.
} 
az utókor emlékezetében, ha nem szabadította volna ki fiait, Neptunust, Plutót és Iuppitert Saturnus és a Titánok kezei közül. Ennek módjáról és részleteiről azonban semmiféle említést nem tesz, annak ellenére, hogy a Genealogiában felhasznált forrásai közül több is tartalmazza az epizódot. Tehát mindaz, amit Boccaccio a Genealogiában a cselekedetek elhallgatásával csupán jelzett, ezzel a megnyilvánulással olvasói tudtára adja. Ezután vonja le a következtetést, hogy az emberek tudatlansága és őrültsége istennői rangra emelte Opsot, templomokat emeltek neki, áldozatokat mutattak be és papokat jelöltek ki számára amellett, hogy az istenek anyjaként tartották számon, ahogyan az a GDG 3, 2-ben is olvasható.

Ami Ops genealógiáját illeti, Boccaccio hü marad a korábban leírtakhoz, annyi különbséggel, hogy apja megnevezése során a Caelum helyett az Uránusz névalakot használja. További különbség, hogy míg a Genealogia egyértelműen Saturnus feleségeként említette Opsot a neki szentelt fejezetben, ${ }^{29}$ addig a De mulieribusban ez az információ kiegészül azzal, hogy az istennő Saturnus nővére ${ }^{30}$ is volt. ${ }^{31}$ Talán azért került bele utóbbi mübe ez az elem is Ops fejezetébe, hogy Boccaccio ezzel is bizonyítsa a hölgy méltatlanságát az istenségeket megillető tiszteletre. Ám az sem zárható ki, hogy mintegy ismeretterjesztő célzattal kapott helyet az információ az elsősorban női olvasóközönségnek szóló müben, így illeszkedve a De mulieribus azon koncepciójába, hogy a szerző a leírások elején röviden bemutatja szereplőit, és szűkebb családjuk tagjairól is említést tesz.

A Genealogiához képest újdonságként jelenik meg a történet, amely szerint a második pun háború idején, amikor a rómaiak szorult helyzet-

\footnotetext{
${ }^{29}$ A GDG 8, 1, 1-ben, a Saturnusról szóló fejezetben azonban Ops az isten testvéreként és feleségeként is szerepel, ez az információ tehát csak Ops saját leírásából hiányzik. Cui ante alia veteres Opim sororem suam sacro vinxere connubio, eique ex ea susceptos plures ascripsere filios.

30 A GDG 4, 1, 3-ban Boccaccio az euhémeroszi Sacra historiát a következőképpen idézi: Exin Saturnus uxorem duxit Opim. Ugyanezt a szövegrészt Lactantius Enniustól idézi, ld. 12. lábjegyzet.

${ }^{31}$ A GDG 3, 1, 1-ben Boccaccio idézi is a később forrásként megnevezett Lactantiust: Uranium potentem virum Vestam habuisse coniugem, et ex ea Saturnum atque Opem et alios suscepisse.
} 
be kerültek, követeket küldtek Attaloshoz, Pergamon királyához, hogy elkérjék tőle az istennő képmását és az áldozatbemutatáshoz szükséges szertartások rendjére vonatkozó utasításokat. Ezután Pessinus városából Rómába vittek egy alaktalan követ, amelyet a rómaiak nagy tisztelettel és csodálattal fogadtak. Később pedig egy templomban helyezték el azt és csodálták, ugyanis az államot megmentő istenségként tekintettek rá. ${ }^{32}$

Ezzel azonban nem csak az új elemek sora, hanem az Opsnak szentelt leírás is szinte lezárul. A fejezetet ugyanis az antik emberek oktalanságát megfeddő rész zárja, amely vakságnak, sőt egyenesen a démonok cselvetésének tartja, hogy egy olyan nőből, mint Ops istennő lehetett, amikor valójában a pokol tüzén égett el. Ezzel a megállapítással Boccaccio egyértelmüvé teszi, hogy az életrajz elején megfogalmazott ",si priscis credimus", vagyis "ha hiszünk elödeinknek" ebben a vonatkozásban számára nem mérvadó.

Boccaccio bizalmatlansága forrásaival szemben és annak elismerése, hogy Ops valójában semmiféle különleges, említésre méltó tettet nem hajtott végre, felveti a kérdést, vajon mi indokolta alakjának beillesztését a De mulieribusba. Míg ez a Genealogia esetében egyáltalán nem merül fel, hiszen ott Ops egyértelmüen meghatározó szerepet tölt be az istenségek családfájában, nem csupán azért, mert számos isten anyjaként tartja számon a mitológiai hagyomány, hanem amiatt is, hogy Boccaccio a filológiai precizitás és a teljességre törekvés jegyében nem mellőzhetett egyetlen olyan istenséget sem, akiről forrásai tudósítottak, legyen bármilyen vitatott a szerepe és a megítélése.

\footnotetext{
${ }^{32}$ Az epizód részletesebben, további elemekkel bővítve megtalálható a De mulieribus (a továbbiakban a szöveghelyek hivatkozásakor DMC) 77, 3-6-ban (De Claudia Quinta muliere romana), ahol Boccaccio leírja, hogy Marcus Cornelius és Publius Sempronius consulsága idején, a második pun háború tizenötödik évében Pessinus városából hajón hozták el az istenek anyjának képmását. A szállítmányt a szenátus által legkiválóbbnak ítélt római polgár, Scipio Nasica várta, matrónákkal körülvéve. A hajó a parthoz közeledve azonban zátonyra futott és senki sem tudta onnan elmozdítani. Ekkor Claudia elkezdett imádkozni az istenséghez és azt kérte tőle, hogy ha kellően tisztának tartja őt, képmása kövesse a nö övét. Ezután Claudia elrendelte, hogy az ifjak távozzanak, a hajót pedig kössék az övéhez. A szobor azonnal megmozdult és könnyedén partot ért a lány nagy dicsőségére, aki ettől fogva a szemérmesség ragyogó példája lett. A leírások megalkotásához Boccaccio valószínúleg Liviust $(29,10)$ és Pseudo-Plinius De viris illustribusát (46) használta.
} 
A kérdés, amelynek tárgyalását a szakirodalom mellőzi, minden kétséget kizáróan nem válaszolható meg, értékelése során különféle lehetőségek merülnek fel. Ha a mü Előszavában keressük rá a választ, akkor meglátásom szerint a véletlenszerüség kínálkozik lehetséges megoldásként. Boccaccio ugyanis abban leírja, hogy olyan hölgyeket illesztett múvébe, akik írás közben eszébe jutottak, így akadnak köztük olyanok is, akik semmiféle említésre méltó dolgot nem tettek annak ellenére, hogy megvolt bennük a kivételes cselekedetek végrehajtásának lehetősége. ${ }^{33}$ Továbbá annak a lehetőségét sem zárom ki, hogy Ops révén akarta Boccaccio illusztrálni saját euhémerizmusát, vagyis azt az elképzelést, amely szerint az antik világ istenségei valójában közönséges földi halandók voltak, akiket kivételes tetteik miatt istenekként kezdtek tisztelni. Hiszen az antikvitás téves vallási elképzeléseinek kevés meggyőzőbb bizonyítéka lehet a keresztény olvasók szemében, mint egy olyan nő, akinek szinte semmi jelentős tette nem maradt az utókorra, mégis istennőként tisztelték. Végül felvetődik az a lehetséges magyarázat is, hogy az Opsnak szentelt fejezettel akarta elökészíteni Boccaccio Claudia Quinta (DMC 77) történetét, hogy az olvasói számára részletesebb ismeretekkel szolgálhasson, pontosan kinek a képmása is került Rómába a második pun háború során. Ám ez utóbbi kevésbé tünik valószínünek, hiszen mindezt abban az egy fejezetben is kifejthette volna, figyelembe véve, hogy más, jelentős tettét, állítása szerint nem kívánta különösebben hangsúlyozni. Továbbá hetvenhárom másik életrajz választja el a két leírást egymástól, ami ez utóbbi magyarázat valószínűségét tovább csökkenti.

Bármilyen írói döntés is állhatott a háttérben, Ops két önálló leírásának összevetése alátámasztja a Genealogia és a De mulieribus között fennálló szoros kapcsolatot, illetve megerősíti annak szükségességét, hogy Boccaccio teljes életművét, így latin nyelvű prózáját is egységben vizs-

\footnotetext{
${ }^{33}$ DMC Proemio, 4: Et ideo, ne merito fraudentur suo, venit in animum ex his quas memoria re; feret in glorie sue decus in unum deducere; eisque addere ex multis quasdam, quas aut audacia seu vires ingenii et industria, aut nature munus, vel fortune gratia, seu iniuria, notabiles fecit; hisque paucas adnectere que, etsi non memoratu dignum aliquid fecere, causas tamen maximis facinoribus prebuere. A müből származó idézet forrása az alábbi kritikai kiadás: ZACCARIA (1967).
} 
gáljuk. Ugyanakkor szem előtt kell tartanunk az egyes művek célkitüzéseit és eltérő célközönségét is, hogy a lehető legpontosabb értelmezési keretek figyelembe vételével tekinthessünk az egyes leírásokra.

Az összevetés során egyértelmüvé vált továbbá, hogy az istennő ábrázolásakor és a róla összegyüjtött ismeretek közvetítésekor egyaránt a középkori irodalmi hagyományt részesítette előnyben Boccaccio, különös figyelmet szentelve Ágoston, Fulgentius, Rabanus Maurus vagy Lactantius müveinek. Rajtuk keresztül szürte meg az antik auktorok értesüléseit, amelyek nem kevésbé voltak homályosak és szinte ugyanannyi, ha nem több kérdést hagytak nyitva, mint amennyit magyarázataik révén tisztázni igyekeztek. A GDG 3, 2-ben olvasható Ops-leírások pedig abba is betekintést engednek, mikor és milyen eredménnyel kerül előtérbe a filológus Boccaccio, és hol érzi szükségét annak, hogy tered engedjen a benne rejlő narrátornak. Ugyanakkor talán Ops példája szemlélteti a leginkább azt a boccacciói felismerést, hogy amit még a Genealogia több fejezetében sem lehetséges alaposan kifejteni és föleg rendszerezni, azt teljességgel hiábavaló a De mulieribus lényegesen letisztultabb és korlátozott szerkezetébe átemelni.

\section{Források}

ZACCARIA 1967

V. ZACCARIA (ed.), Giovanni Boccaccio: De mulieribus claris (Tutte le opere di Giovanni Boccaccio X.), Milano, 1967.

ZACCARIA 1998 V. ZACCARIA (ed.), Giovanni Boccaccio: Genealogie deorum gentilium (Tutte le opere di Giovanni Boccaccio VII-VIII.), Milano, 1998.

\section{Felhasznált irodalom}

KERÉNYI 1977

KIRKHAM 2013

MAZZA 1966

MIANO 2015

MOLINA 2014
KERÉNYI K., Görög mitológia, Budapest, 1977.

V. KIRKHAM, Chronology of Boccaccio's Life and Works, in: V. Kirkham, M. Sherberg, J. L. Smarr (eds.), Boccaccio: A Critical Guide to the Complete Works, Chicago and London, 2013, xiii-xix.

A. MAZZA, L'inventario della 'parva libraria' di Santo Spirito e la biblioteca del Boccaccio, Italia medioevale e umanistica, 9 (1966), $1-74$.

D. MiAnO, The Goddess Ops in Archaic Rome, Bulletin of the Institute of Classical Studies 58 (2015), 98-127.

M. MolinA, Tympanum tuum Cybele: Pagan Use and Christian Transformation of a Cultic Greco-Roman Percussion Instrument, in: Jaume 


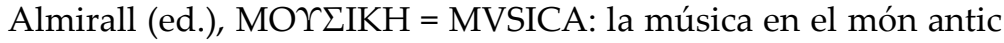
i el món antic en la música, Barcelona, 2014, 51-69.

VÍGH 2019 VíGH É. (szerk.), Állatszimbólumtár A-Z, Szeged, 2019.

\section{Vocavere eam preterea multis nominibus: tracking the Boccaccian Ops}

Ops can be found as a very complex goddess in the ancient literary tradition, considering either the variations of her name or the functions associated to her. She was named, as the goddess of prosperity, wealth, fertility and Earth, in different ways, e.g. Opis, Rhea, Tellus or mostly Cybele, and in line with this, different roles were attributed to her, among which no obvious distinctions were reached neither in the Antiquity, nor in the Middle Ages. In my essay I try to show how Boccaccio interpreted the elements of the ancient literary through the filter of the Medieval tradition. What kind of attributes and interpretations did he received and on the basis of the sources how he created his narratives on Ops in De mulieribus claris and Genealogia deorum gentilium? What kind of contradictions did Boccaccio the philologist and narrator get into and can these ones be unlocked? So the figure of Ops in Boccaccio's interpretation can be a picturesque example to see what kind of challenges had to face an author, trying to elaborate ideas deriving from his ancestors, at the dawn of philology.

Keywords: Ops, Boccaccio, Genealogia deorum gentilium, De mulieribus claris, interpretation of literary sources 